\title{
Karaimistyka jako nieodłączny element turkologii w Wilnie
}

\author{
Halina Kobeckaitè \\ Lietuvos karaimų kultūros bendrija
Karaim Studies as an Integral Part of the Turkology in Vilnius

Summary: The main aim of this article is to describe the role played of two Turkic communities residing in the territory of the Great Duchy of Lithuania from the $14^{\text {th }}$ century onwards - the Karaims and the Tatars - in the appearance and development of oriental and Turkological studies in Vilnius. A short overview of the state of Oriental Studies in Vilnius, in particular in Vilnius University in the $18^{\text {th }}-19^{\text {th }}$ centuries, and its correlation with the local "Orient", is given in the first part of the article. Most of the article focuses on the period between the two world wars, when Karaim and Tatar scholars, educationists and spiritual leaders took a very active role in investigating and popularising their own cultural heritage and Turkic culture in general. Through publications in magazines, the activities of societies and communities, an available pool of effective and skilled experts Karaim and Tatars courses emerged in Vilnius as an equivalent subject to traditional Oriental Studies and Turkology. Their achievements paved the way for the great resurgence in national identity and the revival academic research and teaching on Lithuania's national heritage after it regained its independence in 1990. Research on the Oriental heritage of the Lithuanian Grand Duchy was out of the question during the Soviet period. Today when linguistic and cultural studies and research on Karaim and Tatar culture have become an important feature of Turkology, the Oriental studies programme in Vilnius constitutes a relevant part of professional academic life. 
Keywords: Orient studies, Turcology, Karaims, Karaim studies, Karaim language, Tatars, Lithuania, Vilnius, Trakai, Poland, Vilnius university, Turks, period between the two World wars, revival, national identity

Na Uniwersytecie Wileńskim jeszcze przed jego likwidacją w 1832 r. widoczne były wśród wykładowców i studentów oznaki zainteresowania Orientem, w tym Orientem tureckim. Na przykład prof. Tomasz Husarzewski (1732-1807), który w latach 1783-1805 wykładał historię powszechną, miał zamiar włączyć w swój program „historię wschodnich imperiów i arabską za czasów Mahometa i jego potomków”. W roku 1822 adiunkt Kazimierz Kontrym (1777-1836) wręczył kuratorowi Uniwersytetu, Adamowi Czartoryskiemu (1770-1861) memorandum, w którym oprócz nauczania języka litewskiego postulował również utworzenie specjalnego instytutu dla nauczania tureckiego, perskiego, tatarskiego, ormiańskiego, mongolskiego i arabskiego. W latach 1826-1829 języki perski i arabski wykładał prof. Wilhelm Münnich (1785-1867)².

Chętnych do uczenia się wschodnich języków nie brakowało, choć nie starczyło im czasu, by się gruntownie nauczyć. Po zamknięciu uniwersytetu w $1832 \mathrm{r}$. zostali zmuszeni kontynuować studia w innych uczelniach Rosji. Analizując dzieje orientalistyki swego kraju, naukowcy polscy podkreślają, że „w okresie rozbiorów wraz z rozwojem naukowej orientalistyki w Europie ośrodkiem orientalistyki polskiej staje się Uniwersytet Wileński... Z Wilna wyszli liczni orientaliści, którzy później przyczynili się do rozwoju studiów orientalistycznych zarówno w Rosji, jak i za jej granicami”’.

Prof. Jan Reychman, opisując podróże polskich orientalistów po krajach Dalekiego i Bliskiego Wschodu ${ }^{4}$, wymienia byłych studentów Uniwersytetu Wileńskiego: Aleksandra Chodźkę (1804-1891), Józefa Kowalskiego (1801-1878),

1 Vilniaus universiteto istorija. 1579-1803, red. Vytautas Merkys, Vilnius 1976, s. 273; Algirdas Šidlauskas, Istorija Vilniaus universitete. XVI a. pabaigoje - XIX a. pradzioje, Vilnius 1989, s. 112.

2 Vilniaus universiteto istorija 1803-1940, red. A. Bendžius, J. Kubilius, V. Merkys, Vilnius 1977, s. 93.

3 W. Tyloch, Jezzykoznawstwo orientalne w Polsce, „Przegląd Orientalistyczny”, 1978, 2 (106), s. 136. Zobacz też: J. Reychman, Próby organizacji orientalistyki polskiej $w$ dobie mickiewiczowskiej, „Przegląd Orientalistyczny”, 1954, nr 3, s. 247-264.

4 J. Reychman, Podróżnicy polscy na Bliskim Wschodzie w XIX w., Warszawa 1972, passim. 
Tomasza Zana (1796-1855), Adolfa Januszkiewicza (1803-1857), Józefa Sękowskiego (1800-1858), Ignacego Pietraszewskiego (1796-1869).

Większość wymienionych naukowców wykazywała zainteresowanie narodami orientalnymi zamieszkującymi daleko od naszych stron ojczystych. Tym czasem na terytorium Wielkiego Księstwa Litewskiego już od końca wieku XIV mieszkały dwie grupy etniczne pochodzenia tureckiego, które możemy nazywać „rodzimym Orientem”. Mowa oczywiście o Tatarach i Karaimach. W XIX stuleciu wzmianki o nich w pracach wileńskich naukowców są nieliczne. Choć jak pisze polski historyk, religioznawca Mariusz Pawelec, omawiając obecność tematyki karaimskiej w kulturze i nauce polskiej, ,już prof. Joachim Lelewel zwrócił uwagę, że mowa Karaimów zbliżona jest najbardziej do wymarłego języka kumańskiego, powstałego przed najazdem ludów tatarsko-mongolskich. Uczony ten w połowie XIX wieku trafnie powiązał ludność Karaimską z dawnymi Polowcami. Jemu również zawdzięczamy pierwsze informacje o średniowiecznym Kodeksie Kumańskim"s, jedynie artykuły Tadeusza Czackiego (1765-1813) w „Dzienniku Wileńskim” i edycja źródłowa Antoniego Muchlińskiego (1808-1878) Zdanie sprawy o tatarach litewskich $z 1558$ z tekstem tureckim, które ukazało się w Wilnie w roku $1859^{6}$, są faktycznie poświęcone miejscowemu Orientowi.

Pod wpływem wyżej wymienionych naukowców i panującej wówczas w Europie romantycznej fascynacji wschodnią kulturą, Orientem zainteresował się również Adam Mickiewicz (1798-1855). Podróż na Krym, który potem nazywał „małym Wschodem”, poeta odbył w $1825 \mathrm{r}$. razem z pisarzem, hr. Henrykiem Rzewuskim (1791-1866). Niektóre wątki „Sonetów Krymskich”, które są plonem tej wyprawy, niewątpliwie łączą się z tematyką karaimską. Kilka sonetów na język karaimski przetłumaczyli prof. Ananiasz Zajączkowski i i starszy duchowny gminy trockiej, Szymon Firkowicz?

Fakt spotkania się Mickiewicza w czasie podróży na Krym w 1825 r. z Karaimami, potwierdza list Rzewuskiego z Akmesdżidu (Symferopola) z 29 czerwca

$5 \quad$ M. Pawelec, Obecność tematyki karaimskiej w kulturze i nauce polskiej, [w:] Karaimi, red.

B. Machul-Telus, Warszawa 2012, s. 111.

6 Tamże, s. 104; J. Reychman, Podróżnicy..., s. 27-28.

7 J. Reychman, Podróżnicy..., s. 38.

8 Adam Mickiewiczniń „Kyrym sonetłary”, „Karaj Awazy”, 1931, z. 1, s. 10-13, z. 2, s. 14-18.

9 Joł kała iuśtiunia. Droga nad przepaścią w Czufut Kale, „Myśl Karaimska”, 1925, nr 2, s. 24. 
1825 r. do przebywającej w Odessie marszałkowej Konstancji Szaszkiewiczowej. List ten został opublikowany przez Seraję Szapszała (1873-1961) ${ }^{10}$.

Rzeczywista karaimistyka i tatarystyka pojawiają się w Wilnie dopiero w XX w., kiedy Karaimi i Tatarzy pod wpływem ogólnego ruchu odrodzenia narodowego w Europie zaczynają zastanawiać się nad własną tożsamością. Rozwijanie poczucia tożsamości narodowej przez sam podmiot stanowi ważną przesłankę do rozwoju studiów o tym podmiocie w ogóle.

W początkach XX stulecia ukazują się pierwsze drukowane czasopisma karaimskie w języku rosyjskim: w Moskwie w latach 1911-1912 „Karaimskaâ Žizń”, zaś w Wilnie w latach 1913-1914 „Karaimskoje Slovo”. Autorzy publikowanych w nich artykułów stawiali sobie za cel rozwijanie świadomości narodowej, poznawanie dziejów przodków. Choć wydawane przez amatorów, tytuły te odegrały ważną rolę w konsolidacji narodu, apelując do inteligencji i przypominając jej o zobowiązaniach wobec całej społeczności, o potrzebie podjęcia starań o przetrwanie narodu, rozbudzenie poczucia narodowej tożsamości i jedności.

Niestety, tę ważną działalność przerwała I wojna światowa. Zmuszeni do ewakuacji Karaimi rozproszyli się po różnych miastach Rosji i Krymu i dopiero po roku 1920, kiedy społeczność karaimska powróciła w rodzinne strony, na nowo podjęto prace nad krzewieniem narodowej świadomości i coraz intensywniej je kontynuowano.

Na Uniwersytecie Wileńskim, który wznowił działalność, w latach międzywojennych języki wschodnie nie były wykładane. Dlatego orientalistyka i turkologia w Wilnie zaczęła żyć poza światem akademickim - dzięki „rodzimemu Orientowi”, Karaimom i Tatarom. W ramach ogólnej narodowo-patriotycznej ideologii odrodzonych niepodległych państw, Polski i Litwy, inteligencja karaimska i tatarska również zaczęły prowadzić aktywną działalność narodowo-oświatową. W roku 1921 powstaje w Wilnie Wileńskie Stowarzyszenie Karaimów, rok później w Trokach zaczyna swoją działalność Karaimski Zarząd Duchowny. Podejmują działalność Koło Pań „Katyn Odżahy”, Koło Młodzieży Karaimskiej „Bir Baw”, które później wydawało czasopismo w języku karaimskim „Dostu Karajnyn” („Przyjaciel Karaima”, ukazały się 3 zeszyty). W 1920 r. - po dłuższym wakacie - starszym duchownym w Trokach zostaje wybrany Szymon Firkowicz (1897-1982), młody, energiczny absolwent krymskiego seminarium duchownego, działalność którego zaowocowała nie tylko w czasach międzywojennych, ale

10 S. Szapszał, Adam Mickiewicz w gościnie u Karaimów, „Myśl Karaimska”, 1934, z. 10, s. $1-10$. 
i potem, o czym będzie jeszcze mowa. Życie gminy karaimskiej powoli wracało na właściwe tory.

Jednym z najważniejszych momentów dla omawianego tu tematu jest ukazanie się w Wilnie w 1924 r. naukowo-literacko-społecznego czasopisma „Myśl Karaimska”, na pierwszej stronie którego czytamy, „że w dążeniu do zapewnienia sobie lepszej przyszłości i ułożenia warunków naszego życia zbiorowego wre praca we wszystkich dziedzinach życia karaimskiego"11.

W 1925 r. w Wilnie powstaje Związek Kulturalno-Oświatowy Tatarów Rzeczpospolitej Polskiej, który wydaje „Rocznik Tatarski” (1932-1938, ukazały się 3 zeszyty), a później miesięcznik „Życie Tatarskie” (1934-1939). Tatarzy wileńscy wydają w Warszawie również „Przegląd Islamski” ${ }^{2}$. Artykuły na łamach tych czasopism wykazują, że Tatarzy i Karaimi sami zaczynają badać dzieje swoich narodów, a jednocześnie zachęcają do tego również innych naukowców działających w tym czasie w Wilnie.

Wydarzeniem szczególnie znaczącym dla rozwoju karaimistyki w Wilnie stała się wizyta profesora Tadeusza Kowalskiego w Trokach w 1925 r. Pozwoliła ona Karaimom uświadomić sobie znaczenie ich ojczystego języka dla studiów turkologicznych. W „Myśli Karaimskiej”, której lektura zainspirowała ponoć Kowalskiego do zainteresowania się językiem karaimskim, ogłasza on artykuł o języku karaimskim ${ }^{13}$. „Wycieczka naukowa” do Trok i Wilna zaowocowała wydaniem w roku 1929 w Krakowie pracy w języku niemieckim Die Karaimische Texte im Dialekt von Troki ${ }^{14}$, pierwszej naukowej monografii poświęconej językowi karaimskiemu. Dzięki temu dziełu karaimistyka znalazła się w orbicie zainteresowań europejskiej turkologii, a język karaimski został wprowadzony do ćwiczeń seminaryjnych na uniwersytecie berlińskim ${ }^{15}$. Prof. T. Kowalski był aktywnym uczestnikiem orientalistycznego życia w Wilnie, autorem licznych artykułów na tematy karaimskie. Wszedł w skład kolegium redakcyjnego „Myśli Karaimskiej”, miał również swój udział w wydawaniu „Rocznika Tatarskiego”16. Jego korespondencja z prof. A. Zajączkowskim, opracowana i wydana przez

${ }^{11}$ Od Redakcji, „Myśl Karaimska”, 1924, z. 1, s. 1.

12 T. Bairašauskaité, Lietuvos totoriu leidiniai ir spauda, „Žurnalisto žinynas”, Vilnius 1996, s. 86-95.

13 T. Kowalski, Jezyk karaimski, „Myśl Karaimska” 1926, z. 3, s. 3-7.

14 A. Dubiński, Prace prof. Tadeusza Kowalskiego poświęcone kipczackim elementom etniczno-językowym. „Przegląd Orientalistyczny” 1978, nr 4 (108), s. 369-373.

15 К. Мусаев, Грамматика караимского языка, Moskwa 1964, s. 29; Jezyk karaimski na uniwersytecie berlińskim. „Myśl Karaimska” 1931, t. II, z. III-IV, s. 71.

16 T. Bairašauskaité, op. cit., s. 91. 
prof. Tadeusza Majdę i Marię Emilię Zajączkowską-Łopatto, potwierdza, że prof. T. Kowalski był w Wilnie uważany za „swojego” człowieka ${ }^{17}$.

Pobyt prof. T. Kowalskiego w Trokach był owocny również w innym sensie zainspirował świeżo upieczonego maturzystę Ananiasza Zajączkowskiego do wyjazdu na turkologiczne studia do Krakowa i stania się pierwszym Karaimem z Wilna zawodowo zajmującym się orientalistyką. Tematyka języka karaimskiego, któremu poświęcił swą pracę doktorską ${ }^{18}$, pozostała jednym z głównych obszarów zainteresowań naukowych profesora jako ważny i nieodłączny element studiów turkologicznych.

Innym bardzo znaczącym, a być może najważniejszym wydarzeniem w kształtowaniu się karaimistyki, a także szerzej turkologii i orientalistyki w Wilnie, był przyjazd ze Stambułu do Wilna w 1928 r. znanego orientalisty Hadży Seraji Chana Szapszała, który w 1927 r. został wybrany na stanowisko hachana, duchowego zwierzchnika Karaimów. Z jego przybyciem temat Orientu w Wilnie stał się bardziej widoczny. Pełniąc przede wszystkim funkcje duszpasterskie, S. Szapszał nigdy nie zapominał i o swoim wyuczonym zawodzie, a rozpowszechnianie wiedzy o Oriencie uważał za ważne zadanie swojej misji.

W latach 1930-1939 S. Szapszał wykładał język turecki w wileńskim Instytucie Naukowo-Badawczym Europy Wschodniej i zwiazanej z nim Szkole Nauk Polityczych, uczestniczył w konferencjach turkologicznych w Turcji, jak też zabierał tam swoich studentów, na których potrzeby napisał Wypisy tureckie i słownik turecko-polski $(1932)^{19}$, pierwszy wydany w Polsce podręcznik do nauki języka tureckiego. W roku $1934 \mathrm{w}$ Wilnie została wydana jego monografia Wyobrażenia świętych muzulmańskich a wplywy ikonograficzne katolickie $w$ Persji i stosunki persko-polskie za Zygmunta III. Druga jego praca, Próby literatury ludowej Turków $z$ Azerbajdżanu perskiego (wstęp, teksty, tłumaczenie i azerbajdżańsko-polsko-niemiecki słownik) ukazała się w 1935 r. w Krakowie i do dziś nie straciła swej wartości.

Postać i dokonania S. Szapszała zwróciły na siebie uwagę naukowej społeczności od razu po jego przybyciu do Wilna ${ }^{20}$. Już w roku 1928 został członkiem Polskiego Towarzystwa Orientalistycznego, a w roku 1935 wybrano go

17 Urzeczeni Orientem. Listy Ananiasza Zajązkowskiego do Tadeusza Kowalskiego 1925-1948, red. T. Majda, Warszawa 2013.

18 A. Zajączkowski, Sufiksy imienne i czasownikowe w jezyku zachodnio-karaimskim. Przyczynek do morfologii jezzków tureckich, Kraków 1932.

19 Ö. Emiroğlu, T. Majda, Polska bibliografia turkologiczna, Warszawa 2012, s. 135-136.

20 Seraya Szapszal's Karaim Collection, red. M. Slušinskaite, Vilnius 2003; Hadżi Seraja Chanas Šapšalas pasišventęs tautai ir mokslui. Straipsniu rinkinys, red. H. Kobeckaitè, V. Poviliūnas, I. Senulienè, A. Zagreckaité, Trakai 2011. 
wiceprezesem. Aktywnie uczestniczył w działalności Towarzystwa. Przy jego zaangażowaniu odbyły się w Wilnie dwa zjazdy tej organizacji: II Zjazd PTO w roku 1932 i VI latem 1937 r. Jednym z głównych tematów zjazdów, jak i prac naukowych S. Szapszała, którego prof. T. Kowalski nazwał „bezsprzecznie najlepszym znawcą przedmiotu"21 , stanowiła oczywiście karaimistyka.

W 1929 r. w „Myśli Karaimskiej” ukazał się artykuł S. Szapszała uszczegółowiający wcześniejsze badania o Karaimach w służbie chanów krymskich ${ }^{22}$. Inne jego artykuły znaleźć można niemal w każdym numerze czasopisma, podobnie jak prace prof. A. Zajączkowskiego. Wśród autorów „Myśli Karaimskiej” byli też naukowcy nie Karaimi ${ }^{23}$, znaleźć tam też można publikacje o tematyce bardziej ogólnej. W ten sposób czasopismo to stawało się coraz bardziej periodykiem akademickim o tematyce orientalnej. Również Tatarzy zaczęli w latach międzywojennych prowadzić badania nad dziejami swego narodu ${ }^{24}$. Działacze społeczni i naukowcy reprezentujący obie grupy etniczne poprzez swą działalność naukową stymulowali dalsze badania nad historią i kulturą Karaimów i Tatarów, tworząc w Wilnie właściwą turkologię.

S. Szapszał rozpowszechnianie wśród inteligencji wileńskiej wiedzy o narodzie karaimskim uważał za swój obowiązek. Z jego inicjatywy zostało powołane w roku 1932 Towarzystwo Miłośników Historii i Kultury Karaimskiej ${ }^{25}$ jako „rozsadnik karaimskiej nauki”26. Zostało ono bardzo przychylnie powitane także

21 T. Kowalski, Turecka monografia o Karaimach krymskich, „Myśl Karaimska”, 1929, t. II, z. 2, s. 1.

22 S. Szapszał, Karaimi w stużbie u chanów krymskich, „Myśl Karaimska”, 1929, t. I, z. I, s. $5-22$.

23 Por. M. Morelowski, Tkaniny ludowe karaimskie i sprawa pochodzenia Karaimów krymskich i polskich, „Myśl Karaimska”, 1932-1934, z. 10, s. 37-87; B. Baranowski, Przyczynki do stosunków Karaimów polskich ze Wschodem muzulmańskim, „Myśl Karaimska”, 1937-1938, z. 12, s. 11-19; R. Mienicki, Uniwersal z r. 1688 dla Karaimów trockich, „Myśl Karaimska", 1937-1938, z. 12, s. 20-21; J. Reychman, Tłumacze języków wschodnich w Polsce XVIII wieku, „Myśl Karaimska”, 1946-1947, Seria nowa, tom II, s. 66-78 i inne.

24 A. Jakubauskas, G. Sitdykov, S. Dumin, Lietuvos totoriai istorijoje ir kultūroje, Kaunas 2012, s. 103.

25 Więcej o działalności Towarzystwa zob. S. Gąsiorowski, Towarzystwo Miłośników Historii i Literatury Karaimskiej $w$ Wilnie i jego czlonkowie w latach 1932-1939, [w:] Karaj kiuńliari. Dziedzictwo narodu karaimskiego we wspólczesnej Europie, red. M. Abkowicz, H. Jankowski, Wrocław 2004, s. 71-83; H. Kobeckaitè, Karaimu istorijos ir literatūros mylettoju draugijos veikla Vilniuje 1932-1939 metais. Vilniaus kuiltūrinis gyvenimas. Draugiju reikšme 1900-1945, Vilnius 2008, s. 77-85.

26 S. Szapszał, Adam Mickiewicz w gościnie u Karaimów, „Myśl Karaimska”, 1934, z. 10, s. 1. 
przez Tatarów wileńskich, a jego członkiem honorowym został prof. T. Kowalski. Zapraszając prof. T. Kowalskiego do przyjęcia tej godności, S. Szapszał tak pisał do niego:

„Przyszedłeś do nas z wielką życzliwością i otwartym sercem, niosąc słowa otuchy i pokrzepiania i nawołując do ratowania zagrożonej spuścizny po naszych przodkach, skarbu narodowego - naszego języka ojczystego. Swym szlachetnym zapałem i niestrudzoną pracą dałeś nam godny przykład jak należy cenić i szanować zabytki naszej kultury duchowej.

Z właściwą sobie energią i ogromną wiedzą Wielkiego Męża Nauki zabrałeś się do opracowania naszego języka karaimskiego i wydałeś wiele rozpraw z dziedziny karaimoznawstwa: „Teksty Karaimskie w narzeczu trockim”. Książka ta powitana przez orientalistów Europy z wielkim entuzjazmem, stanowi chlubne kartę w dziejach nauki polskiej, dla nas Karaimów tym chlubniejszą, że na niej zostało wypisane także i nasze imię. Spełniłeś najwyższy cel nauki: wydobycie na jaw prawdy, a sprostowawszy dotychczasowe mylne poglądy badaczy na język karaimski, ogłosiłeś światu wielką doniosłość tego języka dla studiów naukowych z zakresu turkologii.

Jakoż wkrótce sprawdziły się słowa Syrokomli: «Naprawdę, niwa badan miejscowych, jak nasze chlebne niwy, poty najlepiej rodzi, dopóki jest jeszcze nowiną. Błogosławiony pierwszy, kto się jął do trzebieży leżących odłogiem, niepożytecznych na pierwszy rzut oka obszarów, kto pierwszy zapuściwszy lemiesz lub rydel, poruszy odwieczne karcze na nowinie, bo mnogie i korzystne będą plony jego mozołu».

Plony Twego mozołu są znane i widoczne: język karaimski opuścił skromne siedlisko szkółki parafialnej i zajął wreszcie godne miejsce obok pokrewnych języków tureckich w najwyższej świątyni nauki: opracowane przez Ciebie Teksty Karaimskie są czytane i objaśniane na Uniwersytetach nawet za granicą - w Niemczech. A wśród nas, Karaimów, ziarna rzucone przez Ciebie wydały bujną roślinność. Przecież to Ty dźwignąłeś nasze pismo narodowe Myśl Karaimska na wyżyny, z których się dzisiaj szczerze szczycimy.

Przeto I-sze Walne Zebranie nowopowstałego Towarzystwa Miłośników Historii i Literatury Karaimskiej w dniu 24 kwietnia 1932 r. jednogłośnie uchwaliło na podstawie \$9 Statutu Towarzystwa nadać Ci, Wielce Czcigodny Panie Profesorze, godność Członka Honorowego Towarzystwa Miłośników Historii i Literatury Karaimskiej. Uprzejmie prosimy o łaskawe przyjęcie dyplomu na tę godność nadaną Tobie w dowód głębokiej czci i szczerego szacunku, jaki żywimy do Ciebie i w dowód niezmiernej wdzięczności, jaką chowamy w sercach naszych." ${ }^{27}$.

27 Lietuvos MA Vrublevskio bibliotekos Rankraščių skyrius, S. Šapšalo fondas, F.143-132. 
Dzięki działalności członków Towarzystwa wiedza o Karaimach, tej najdalej na zachód zamieszkałym ludzie tureckim docierała do innych krajów. 4 kwietnia 1934 r. prof. M. Morelowski wygłosił wykład o ornamentyce karaimskiej sztuki ludowej na Uniwersytecie w Brukseli, w tym samym roku S. Szapszał, jako prezes honorowy Towarzystwa wraz z prof. A. Zajączkowskim wzięli udział w II Kongresie Języka Tureckiego w Stambule, zaś w roku 1937 S. Szapszał i S. Firkowicz odwiedzili Paryż i Berlin.

Również naukowcy zagraniczni wykazywali zainteresowanie Karaimami. Świadczy o tym, na przykład, przyjazd do Wilna, Trok i Halicza włoskiego antropologa i statystyka prof. Corrado Giniego (1884-1965). Wyniki jego badań wskazujące, że grupa krwi Karaimów jest taka sama jak innego ludu tureckiego, a mianowicie żyjących nad Wołgą Czuwaszy, zostały opublikowane we włoskiej prasie ${ }^{28}$.

Oficjalni goście, którzy w okresie międzywojennych odwiedzają Wilno, nierzadko jadą również do Trok, by spotkać się z Karaimami budzącymi szczególne zainteresowanie ze względu na swoją przynależność do świata tureckiego. Członek parlamentu Turcji, Reszit Safet Bej, odwiedzając w 1930 r. Troki, porozumiewał się z Karaimami w swoim ojczystym języku i, jak głosi trocka tradycja, miał oznajmić, że czuje się jak na brzegu Złotego Rogu w Stambule.

Nie ma w tym nic dziwnego, wszak w tym okresie karaimska gmina w Trokach była bardzo prężna, język karaimski rozbrzmiewał w każdym domu, na ulicy i w świątyni. Warto w tym miejscu wspomnieć o działalności starszego duchownego gminy karaimskiej w Trokach, Szymona Firkowicza. Rola tej postaci w dziejach Karaimów i przetrwaniu ich języka i kultury jest wyjątkowa. Oprócz pełnienia duszpasterskich obowiązków był on nauczycielem języka, poetą, dramaturgiem i niewątpliwym autorytetem w sprawach karaimskich nie tylko na Litwie, ale również na Krymie, w Polsce i w innych krajach. Szczególną rolę pełnił po II wojnie światowej jako jedyny karaimski duchowny na Litwie żaden karaimski ślub, żadne urodziny dziecka, żaden też pogrzeb nie odbył się bez jego modlitwy i błogosławienia. Nie był orientalistą, ale posiadał rozeznanie w przedmiocie, doskonałą znajomość języka ojczystego. Jego zbiory folklorystyczne, kartoteka leksyki, poezje w języku karaimskim stały się przedmiotem badań tak prof. T. Kowalskiego, jak i późniejszych naukowców. Firkowicz był również autorem publikacji w „Myśli Karaimskiej”, napisał krótki modlitewnik

28 C. Gini, I caraimi di Polonia e di Lituania, „Genus”, t. II, nr 1-2, 1936, s. 22-24. 
Kołtchałar (1935) i rozprawkę O Karaimach $w$ Polsce (1938). Mówiąc więc o karaimistyce w Wilnie, nie sposób pominąć działalności Sz. Firkowicza ${ }^{29}$.

Ważnym czynnikiem zachęcającym do badań nad Karaimami i stymulującym je była „Myśl Karaimska”, założona jako czasopismo oświatowo-kulturalne, przejęte następnie przez Towarzystwo Miłośników Historii i Literatury Karaimskiej i od 1934 r. wydawane przez prof. A. Zajączkowskiego jako redaktora naczelnego. W miarę upływu czasu pismo to ewoluowało w stronę czasopisma naukowego. Powaga i wysoka wartość publikacji „Myśli Karaimskiej”, a także aktywność skupionych wokół periodyku badaczy i działaczy, zwłaszcza S. Szapszała, A. Zajączkowskiego, Sz. Firkowicza, T. Kowalskiego pozwala twierdzić, że w Wilnie w okresie międzywojennym karaimistyka i tatarystyka były nie tylko ważnym elementem studiów turkologicznych, ale faktycznie stanowiły ich sedno. W czasie bowiem w Wilnie innych badań nad Orientem nie prowadzono.

Po II wojnie światowej nie mogło być mowy o studiach turkologicznych w Wilnie - wszystkie ośrodki zostały skoncentrowane w Moskwie i Leningradzie oraz po części w Baku, gdzie ukazywało się czasopismo „Sovetskaja tiurkologija”. S. Szapszał w 1940 i powtórnie w 1945 r. został zmuszony zrezygnować z obowiązków duszpasterskich. Został pracownikiem naukowym w Instytucie Historii Akademii Nauk Litwy. W swoim życiorysie pisanym w 1954 r. wyraził to tak: "otkazalsa od duchovnogo stana i vstupil na put' sovetskogo učonogo"30. Jak inaczej można to było wtedy określić?

Niestety, nie pozwolono mu wykładać języków wschodnich na uniwersytecie i znajomość ich mógł wykorzystywać jedynie przy opracowywaniu rękopisów z wileńskiego Muzeum Historyczno-Etnograficznego i biblioteki uniwersyteckiej, a także przy przygotowywaniu katalogu swej prywatnej kolekcji orientaliów, która została znacjonalizowana w roku 1951. Napisał również kilka prac pozostających w rękopisie w jego archiwum przechowywanym w Bibliotece Wróblewskich Litewskiej Akademii Nauk w Wilnie ${ }^{31}$.

29 T. Kowalski, Die Karaimische Texte im Dialekt von Troki, Kraków 1929, s. 293; A. Dubiński, Szymona Firkowicza twórczość literacka w jezyku karaimskim, [w:] Caraimica, Warszawa 1994, s. 201-210 (artykuł ukazał się pierwotnie w języku rosyjskim pt. Literaturnoe tvorčestvo Simona Firkoviča (na karaimskom jazyke) w miesięczniku Związku Pisarzy Litewskich „Vilnius” 1993, nr 8, Wilno, s. 126-133).

30 Lietuvos MA Vrublevskio bibliotekos Rankraščių skyrius, S. Šapšalo fondas, F.143.

31 Tamże; V. Pšibilskis, Karaimu tautos patriarchas. Hadżi Seraja Chanas Šapšalas. Pasišventęs tautai ir mokslui, Trakai 2011, s. 15-22. 
Najcenniejszym i najważniejszym zadaniem, które realizował S. Szapszał w tym okresie, był Słownik karaimsko-rosyjsko-polski2 ${ }^{32}$ Współpracował z pozostałymi uczestnikami tego przedsięwzięcia, znanym radzieckim turkologiem prof. Nikolajem Baskakowem (1905-1995) oraz reprezentującym Polską Akademię Nauk prof. A. Zajączkowskim (1903-1970) i jego młodszymi kolegami: Włodzimierzem Zajączkowskim (1914-1982) i Aleksandrem Dubińskim (1924-2002). W Trokach nad kartoteką na potrzeby słownika od dawna nieoficjalnie pracował starszy duchowny Sz. Firkowicz.

S. Szapszał jako znany turkolog był po roku 1953 niejednokrotnie zapraszany na seminaria i konferencje turkologiczne, a nawet na posiedzenia Prezydium AN do Moskwy ${ }^{33}$, mimo to autorytet ani jego, ani innych wybitnych naukowców nie wystarczył, by słownik ukazał się od razu po zakończeniu prac nad jego redakcją. Stało się to dopiero w roku 1974, kiedy A. Zajączkowskiego i S. Szapszała nie było już, niestety, wśród nas. Słownik ten do dnia dzisiejszego jest jedyną wiarygodną współczesną edycją materiału leksykalnego, niezbędnym źródłem dla wszystkich, którzy w jakikolwiek sposób zajmują się językiem karaimskim.

Chociaż turkologia jako nauka akademicka w Wilnie w czasach powojennych nie istniała, pisanie o Karaimach i Tatarach było praktycznie niemożliwe, a kraje Orientu pozostawały fizycznie niedostępne, zainteresowanie nimi w społeczeństwie nie malało. Tę lukę starali się wypełnić nie naukowcy, lecz literaci i tłumacze. Wydawnictwa kierowały się ściśle określonymi regułami polityki wydawniczej - pod hasłem "Literatura narodów Związku Radzieckiego" drukowano przede wszystkim dzieła autorów pochodzących z Azji Środkowej, pozwalało to jednak choć częściowo wypełniać braki w wiedzy o Oriencie. W ten sposób czytelnik litewski mógł się zapoznać z rubajatami Omara Chajjama, gazelami Hafiza, wierszami azerskiego poety Sameda Vurguna, eposem „Dede Korkut”, twórczością kirgiskiego pisarza Czingisa Ajtmatowa, historią władcy Maveranachru i astronoma Uług Bega, poematami Nizamiego i innymi dziełami literatury orientalnej.

Sytuacja się zmieniła dopiero po powstaniu ruchu odrodzenia „Sąjūdis” w 1988 r. i odzyskaniu przez Litwę niepodległości dwa lata później. Najpierw ożył „rodzimy Orient” - powstały organizacje społeczno-kulturalne zarówno

32 Karaimsko-russko-pol'skij slovar', red. N. A. Baskakov, A. Zajončkovskij, S. M. Šapšal, opr. N. A. Baskakow, A. Dubiński, Ch. F. Ishakowa, R. M. Iżbułatowa, K. Musajew, S. M. Szapszał, A. Zajączkowski, W. Zajączkowski, Moskwa 1974.

33 Lietuvos MA Vrublevskio bibliotekos Rankraščių skyrius, S. Šapšalo fondas, F.143-108. 
Karaimów, jak i Tatarów. Oparte na dorobku przedwojennym karaimistyka i tatarystyka ponownie zaowocowały, stając się zaczątkiem nowoczesnej turkologii w Wilnie. Spuścizna tych dwóch narodów stała się przedmiotem badań i tematem publikacji. Nasz Związek Kulturalny Karaimów Litewskich organizuje międzynarodowe konferencje naukowe, jak na przykład te poświęcone 30 rocznicy śmierci S. Szapszała w 1991 r. i 10 rocznicy zgonu Sz. Firkowicza w 1992 r. We współpracy ze Związkiem Kulturalnym Tatarów Litewskich zorganizowaliśmy też pierwszą wspólną międzynarodową konferencję o symbolicznej nazwie „Kipczacko-turecki Orient na Litwie. Historia i perspektywa badań”, która odbyła się w Wilnie w 1993 r. dla uczczenia 90 rocznicy urodzin prof. Ananiasza Zajączkowskiego ${ }^{34}$. Wspólnie pracowaliśmy też nad organizacją w Wilnie konferencji poświęconych 600 i 610-leciu osiedlenia Karaimów i Tatarów na Litwie ${ }^{35}$.

Wydarzenia te nie tylko pomogły nam zwrócić uwagę na istnienie własnego Orientu, ale również stały się inspiracją dla licznych publikacji z zakresu historii kultury Karaimów litewskich, ich literatury i języka, dla badań nad liczną i rozsianą po różnych krajach karaimską spuścizną. Poczesne miejsce w tych dokonaniach zajmują prace starszego duchownego Michała Firkowicza (1924-2000): pierwszy podręcznik do nauki języka karaimskiego Mień karajče ürianiam $^{36}$, dwa tomy modlitewnika Karaj dińliliarniń jalbarma jergialiari ${ }^{37}$, zbiór przekładów Psalmów na karaimski David Bijniń machtav čozmachlary ${ }^{38}$, modlitewnik zawierający codzienne modlitwy Karaj koltchalary ${ }^{39}$, redakcja i edycja XVII-wiecznych przekładów Księgi Przysłów Šelomonun mašallary ${ }^{40}$, kalendarz

34 Materiały konferencji są dostępne w publikacji Kipčiaku tiurkų Orientas Lietuvoje. Istorija ir tyrimu perspektyva, red. T. Bairašauskaitė, H. Kobeckaitė, Vilnius 1994.

35 Materiały konferencji są dostępne w Orientas Lietuvos Didżiosios Kunigaikštijos visuomenes tradicijoje: totoriai ir karaimai. Orient in the social tradition of the Grand Duchy of Lithuania: Tatars and Karaims. Orient $w$ tradycji społeczeństwa Wielkiego Ksiestwa Litewskiego: Tatarzy i Karaimi, red. T. Bairašauskaitè, H. Kobeckaitè, G. Miškinienė, Vilnius 2008.

36 M. Firkovičius, Mień karajče ürianiam, Vilnius, 1996.

37 Karaj dińliliarniń jalbarmach jergialiari, opr. M. Firkovičius, tom I Vilnius 1998, t. II Vilnius 1999.

38 David bijnin machtav čozmachlary. Psalmès, opr. M. Firkovičius, Vilnius 1994.

39 Karaj koltchalary, opr. M. Firkovičius, Vilnius 1993.

40 Šlomonun mašallary. Süleymann meselleri. Patarlių knyga (Proverbia), opr. M. Firkovičius, Ankara 2000. 
karaimski do roku 2051 Karaj kalendary ${ }^{41}$, zbiór poezji karaimskich ${ }^{42}$, napisane wspólnie z prof. Timurem Kocaoğlu rozmówki karaimskie wraz z gramatyką języka karaimskiego w języku angielskim ${ }^{43}$.

Ukazał się ponadto przygotowany przez Karinę Firkavičiute zbiór poezji karaimskiej Čypčychlej učma Trochka $a^{44}$ z przekładami na język litewski. K. Firkavičiute w swojej pracy doktorskiej obronionej w roku 2001 opracowała muzykę karaimską i opublikowała szereg artykułów na ten nigdy dotąd nie poruszany temat ${ }^{45}$.

Warto w tym miejscu podkreślić, że sięgnęły po pióro również osoby prywatne, członkowie karaimskiej społeczności, słusznie uważający, że ich znajomość języka ojczystego nie powinna zaginąć i pójść na marne. Mam tu na myśli słowniki polsko-karaimskie i rosyjsko-karaimskie, ułożone i opublikowane przez Marka Ławrynowicza, Szymona Juchniewicza, Gabriela Józefowi$\mathrm{cza}^{46}$. Choć są to prace amatorskie i dostrzega się w nich niekiedy niedostatek profesjonalnego podejścia do przedmiotu, co powoduje czasami, jak słusznie zaznaczył M. Németh, brak wiarygodności ${ }^{47}$, wobec stale zmniejszającej się liczby użytkowników tego języka są to jednak przedsięwzięcia warte najwyższej pochwały.

Jeśli chodzi o akademicką turkologię i orientalistykę w Wilnie, tu również nastąpiły poważne zmiany. Na Uniwersytecie Wileńskim już od 20 lat

${ }^{41}$ Karaj kalendary 2001-2051, opr. M. Firkovičius, K. Firkavičiūtė, V. Maškevič, Vilnius 2001.

42 Карай йырлары, red. M. Firkovičius, Vilnius 1989.

43 T. Kocaoglu, M. Firkovičius, Karay. The Trakai Dialect. Languages of the World/ Materials. 458. LINCOM EUROPA, 2006.

44 Čypčychlej učma Trochka. Lietuva karajlarnyn jyrlary. I Trakus paukščiu plasnosiu. Lietuvos karaimu poezija, red. K. Firkavičiūtè, Vilnius 1997.

45 K. Firkavičiūtè, Ǐ̌ karaimu apeigines tautosakos, „Tautosakos darbai”, 1992, I (VIII), s. 239-248; K. Firkavičiūtè, Lithuanian Karaims. A multicultural musical minority, [w:] Ethnic relations and musical folklore. Vilnius 2002, s. 129-135; K. Firkavičiūtè, Karaim minority in Lithuania: Recent research about ancient music, [w:] Manifold identities: studies on music and minorities, London 2004, s. 262-271; K. Firkavičiūtè, Muzyka $w$ kulturze karaimskiej, [w:] Karaimi, s. 73-91 i inne.

46 M. Lavrinovič, Русско-караимский словарь / Urus-Karaj sioźliugiu, Trakai 2012; G. Józefowicz, Słownik polsko-karaimski w dialekcie trockim, Troki-Wilno-Warszawa-Wrocław-Gdańsk-Nashville 2008; S. Juchniewicz, Podręczny słownik polsko-karaimski, Wrocław 2008.

47 M. Németh, Przeszłość, teraźniejszość i przyszłość karaimskiej działalności kulturalnojęzykowej, [w:] Karaimi, s. 70. 
nauczany jest język turecki. Powstał tu ośrodek orientalistyczny, w którym oprócz tureckiego wykłada się języki chiński, arabski, perski, japoński. Dzięki staraniom prof. Ewy Csató Johanson w ramach międzynarodowego programu prowadzony jest wirtualny kurs języka karaimskiego, a Letnia Szkoła Języka Karaimskiego, która już od jedenastu lat odbywa się w Trokach, stanowi również swoisty bodziec do podejmowania nowych badań.

Jak wynika z powyższego, studia orientalistyczne w Wilnie nabierają coraz bardziej akademickiego, fachowego charakteru. Świat naszego rodzimego Orientu otwiera się na zewnątrz. My sami również zaczęliśmy bardziej interesować się własną spuścizną historyczną i świat to dostrzega. Podwaliny, które położyli swymi pracami wspomniani wyżej naukowcy wileńscy okresu międzywojennego, stały się bezcennym fundamentem współczesnej karaimistyki i tatarystyki, nieodłącznego elementu składowego studiów turkologicznych nie tylko w Wilnie. Warto dlatego popierać wszelkie działania w tej dziedzinie. 